\title{
Telaah Efektivitas Mekanisme Pemberhentian Presiden Indonesia: Perbandingan Praktik Amerika Serikat dan Korea Selatan
}

\author{
Muhammad Yoppy Adhihernawan* \\ University of Padjadjaran, Bandung, Indonesia
}

\section{Annisa Nur Fadhila \\ University of Padjadjaran, Bandung, Indonesia}

\begin{abstract}
Impeachment characterizes presidential systems as implemented in various countries. This study aimed to examine the rule and practice on the impeachment of the President and/or Vice President in Indonesia, with reference to the United States and South Korea. Then, it analyzed how this mechanism is effective to be implemented in Indonesia. This study used a juridical research method with a comparative law approach. This study indicated differences in impeachment in the United States, South Korea, and Indonesia. The impeachment mechanism in the United States only involved representative institutions, but that in Indonesia and South Korea required judicial intervention. In particular, Indonesia's impeachment dealt with the decision that remained in the hands of the political institution. In South Korea, the final decision ended in the judicial institution. Through this comparison, Indonesia should reformulate the impeachment mechanism. First, the final impeachment decision must be in the Constitutional Court. Second, the decision on impeachment must rest with the People's Consultative Assembly.
\end{abstract}

KEYWORDS: Impeachment, Indonesia, South Korea, United States.

Copyright (C) 2021 by Author(s)

This work is licensed under a Creative Commons Attribution-ShareAlike 4.0 International License. All writings published in this journal are personal views of the authors and do not represent the views of this journal and the author's affiliated institutions.

\section{HOW TO CITE:}

Adhihernawan, Muhammad Yoppy \& Annisa Nur Fadhila, "Telaah Efektivitas Mekanisme Pemberhentian Presiden Indonesia: Perbandingan Praktik Amerika Serikat dan Korea Selatan" (2021) 1:2 Jurnal Kajian Pembaruan Hukum 228-277. DOI: $<$ https://doi.org/10.19184/jkph.v1i2.24453>.

Submitted: 30/05/2021 Reviewed: 04/06/2021 Revised: 25/07/2021 Accepted: 27/07/2021

\footnotetext{
*Corresponding authors' e-mail: yoppyadhi@gmail.com
} 


\section{PENDAHULUAN}

Salah satu ciri dari sistem pemerintahan presidensiil yakni dikenal dengan adanya prinsip bahwa Presiden sebagai pemegang dari pusat kekuasaan dan tanggung jawab terbesar dalam negara. Beberapa negara menerapkan sistem pemerintahan presidensiil, seperti Amerika Serikat dan Korea Selatan dikenal adanya mekanisme impeachment. ${ }^{1}$ Impeachment merupakan mekanisme pemberhentian Presiden dan/atau Wakil Presiden pada masa jabatannya dengan disertai alasan-alasan seperti telah melakukan pelanggaran hukum berupa penghianatan terhadap negara, korupsi, penyuapan, tindak pidana berat lainnya, atau perbuatan tercela dan/atau pendapat bahwa Presiden dan/atau Wakil Presiden tidak lagi memenuhi syarat sebagai Presiden dan/atau Wakil Presiden, ${ }^{2}$ selain itu, ada juga syarat-syarat khusus dalam pengusulan pemberhentian Presiden dan/atau Wakil Presiden seperti pengajuan usul dilakukan oleh Dewan Perwakilan Rakyat (DPR) kepada Majelis Permusyawaratan Rakyat (MPR) dengan terlebih dahulu mengajukan permintaan kepada Mahkamah Konstitusi (MK) untuk memeriksa, mengadili, dan memutus DPR bahwa Presiden dan/atau Wakil Presiden telah melakukan pelanggaran hukum. ${ }^{3}$

Pada hakikatnya impeachment merupakan peradilan politik bagi pejabat negara, karena proses dakwaan terhadap pejabat sipil oleh lembaga legislatif. ${ }^{4}$ Lalu Hamdan Zoelva berpendapat bahwa: ${ }^{5}$

"impeachment merupakan suatu pengawasan legislatif yang bersifat luar biasa terhadap eksekutif dan merupakan tindakan politik dengan adanya hukuman yang dijatuhkan kepada eksekutif berupa pemberhentian dari jabatannya dan larangan untuk memegang suatu

1 Hamdan Zoelva, Pemakzulan Presiden di Indonesia (Jakarta: Sinar Grafika, 2011).

2 Lihat Pasal 7A Undang-Undang Dasar Negara Republik Indonesia Tahun 1945 Perubahan Ketiga.

$3 \quad$ Ibid. Pasal 7B ayat (1).

4 Zoelva, supra note 1 at 9 .

5 Ibid. 
jabatan, hukuman ini bukan berbentuk hukuman pidana ataupun pengenaan sanksi ganti kerugian."

Pada konteks ketatanegaraan Indonesia, presiden memegang kekuasaan tertinggi atas pemerintahan negara. ${ }^{6}$ Berdasarkan ketentuan di dalam Undang-Undang Dasar Negara Republik Indonesia Tahun 1945 (UUD NRI 1945), mengatur bahwa Presiden dan/atau Wakil Presiden di tengah masa jabatannya tidak dapat dijatuhkan oleh legislatif kecuali terdapat alasan-alasan khusus yang melatarbelakangi tindakan tersebut. Sehingga dalam perubahan ketiga UUD NRI 1945 mengatur mengenai mekanisme impeachment atau dikenal dengan pemakzulan. UUD NRI 1945 mengatur dalam proses impeachment adanya perlibatan MK sebagai lembaga yang memutuskan terbukti atau tidaknya tindakan Presiden dan/atau Wakil Presiden untuk di-impeach berdasarkan pendapat dari DPR.7

Adanya perlibatan dari MK yang merupakan unsur hukum ${ }^{8}$, tidak hanya ada di Indonesia tetapi di Korea Selatan pun memberlakukan hal tersebut. Perbedaannya adalah keputusan akhir impeachment presiden di Korea Selatan berada pada keputusan Mahkamah sedangkan Indonesia harus diserahkan kembali kepada unsur politik yaitu MPR dengan alasan mengembalikan keputusan kepada lembaga yang memegang peran kedaulatan rakyat, dalam hal ini memiliki kesamaan dengan Amerika Serikat.

Sementara itu, dalam sejarah ketatanegaraan Indonesia telah tercatat pernah memakzulkan presiden sebanyak dua kali, dimana sejarah tersebut menimbulkan permasalahan tentang proses dan mekanisme serta alasan yang digunakan dalam upaya memakzulkan seorang presiden. Pada saat itu adanya tarik ulur kepentingan yang bermain

6 Undang-Undang Nomor 17 Tahun 2014 tentang Majelis Permusyawaratan Rakyat, Dewan Perwakilan Rakyat, Dewan Perwakilan Daerah, dan Dewan Perwakilan Rakyat Daerah.

$7 \quad$ Ibid. Pasal 7B ayat (4) dan (5).

8 Maksud dari unsur hukum disini adalah unsur penegak hukum yang terbebas dari kepentingan ataupun pengaruh politik apapun, hal tersebut dikarenakan Mahkamah Konstitusi sebagai lembaga peradilan 
didalamnya yang akhirnya menyebabkan terjadi gangguan terhadap semangat konstitusi, secara konstitusional UUD NRI 1945 menegaskan bahwa negara berdasarkan hukum berarti yang harus dijunjung tinggi adalah hukum namun pada kenyataannya hukum merupakan faktor yang dijadikan nomor dua, bahkan tidak jarang adanya intervensi kepentingan politik. ${ }^{9}$ Dapat peneliti katakan bahwa terdapat kerancuan antara sistem pemerintahan presidensial dan pemerintahan parlementer bila melihat dari proses pemakzulan kedua Presiden Indonesia terdahulu. ${ }^{10}$

Persoalan sebenarnya ketika Indonesia telah mempunyai proses impeachment di dalam konstitusi, proses tersebut tidak mengatur lebih lanjut mengenai persoalan-persoalan teknis sehingga masih diupayakan formulasi yang tepat terhadap hal tersebut. Persoalanpersoalan tersebut salah satunya seperti apakah tepat disatukannya pelanggaran hukum baik itu pelanggaran hukum berat dan ringan (tercela) yang dilakukan oleh Presiden dan/atau Wakil Presiden yang menjadi alasan impeachment oleh DPR pada akhirnya diputuskan oleh MPR dalam hal ini sebagai unsur politik bukan kepada MK sebagai unsur hukum.

Berdasarkan latar belakang yang telah disampaikan, maka tulisan ini akan membahas mengenai: Pertama, bagaimana pelaksanaan proses impeachment Presiden dan/atau Wakil Presiden di Amerika Serikat, Korea Selatan, dan Indonesia? Kedua, bagaimana mekanisme impeachment Presiden dan/atau Wakil Presiden yang efektif untuk diterapkan di Indonesia? Untuk menjawab pertanyaan-pertanyaan tersebut, penulis akan melakukan perbandingan kasus impeachment di Amerika Serikat dan Korea Selatan untuk melihat efektifitas keterlibatan dari lembaga peradilan. Selain itu, berdasarkan rumusan masalah tersebut, tujuan dari penelitian ini adalah: Pertama, untuk

9 Fatkhurohman \& Miftachus Sjuhad, "Memahami Pemberhentian Presiden (Impeachment) Di Indonesia (Studi Perbandingan Pemberhentian Presiden Soekarno dan Presiden Abdurrahman Wahid)" (2010) 3:1 J Konstitusi 165-184 at $169-170$.

10 Ibid at 170. 
mengetahui dan memahami pelaksanaan proses impeachment Presiden dan/atau Wakil Presiden di Amerika Serikat, Korea Selatan, dan Indonesia; Kedua, untuk menganalisis bagaimana mekanisme impeachment Presiden dan/atau Wakil Presiden yang efektif untuk diterapkan di Indonesia.

\section{METODE}

Spesifikasi penelitian ini adalah yuridis normatif yaitu penelitian hukum terhadap norma-norma hukum positif, asas-asas, prinsipprinsip, dan doktrin-doktrin hukum. ${ }^{11}$ Penelitian hukum normatif merupakan penelitian dengan mengaitkan teori-teori dengan masalah yang sedang diteliti serta meneliti terhadap kaidah-kaidah dan asas-asas hukum. ${ }^{12}$ Sifat dari penelitian ini adalah deskriptif analitis yaitu menggambarkan dan menguraikan serta sekaligus menganalisis mengani fakta-fakta melalui pendekatan peraturan perundang-undangan. ${ }^{13}$

Selain itu, pendekatan yang digunakan dalam penelitian ini adalah metode pendekatan perbandingan hukum, dengan tujuan untuk mendalami pemahaman terkait dengan topik penelitian karena akan melihat praktik langsung di beberapa negara terkait. ${ }^{14}$ Penulis menggunakan metode perbandingan hukum sesuai dengan sebagai alat bantu untuk mereformasi hukum tata negara darurat Indonesia, sejalan dengan apa yang menurut Peter de Cruz salah satu fungsi dari metode perbandingan hukum adalah as an aid to legislation and

11 Johnny Ibrahim, Teori dan Metedologi Penelitian Hukum Normatif (Surabaya: Bayumedia, 2008) at 282.

12 Soerjono Soekanto \& Sri Mamuji, Penelitian Hukum Normatif: Suatu Tinjauan Singkat (Jakarta: RajaGrafindo Persada, 1994) at 13.

13 Peter M Marzuki, Penelitian Hukum (Jakarta: Kencana Prenada Media Group, 2005) at 96.

14 Rudolf B Schlesinger, Comparative Law: Cases Text Materials, 2d ed (Brooklyn: Foundation Press, 1959) at 1. 
law reform, yakni perbandingan hukum dapat digunakan sebagai alat bantu dalam membantu gagasan reformasi hukum di suatu negara. ${ }^{15}$

Pendekatan perbandingan hukum tata negara sendiri digunakan penulis untuk melihat pembatasan kekuasaan pada masa keadaan darurat di dalam konstitusi negara lain dan bagaimana pengaruhnya bagi penanganan keadaan darurat di negara tersebut. Perbandingan tersebut harapannya akan dapat dijadikan pelajaran ataupun contoh bagi Indonesia dalam mereformulasi hukum mengenai impeachment, sehingga penting bagi penulis untuk mencari negara yang dijadikan objek perbandingan, adalah negara yang pernah mengalami impeachment yang diperjalankan sesuai dengan ketentuan konstitusi di negara tersebut, yakni Korea Selatan dan Amerika Serikat.

Hal tersebutlah yang membuat penulis mengacu pada tingkatan perbandingan hukum menurut Francois Venter, memilih perbandingan dalam tingkatan mengkaji tidak hanya sebatas teks konstitusi (comparison of the law of the constitution) saja, melainkan memilih tingkatan perbandingan yang kedua, yaitu perbandingan yang berusaha mengamati bagaimana pada praktiknya ketentuan yang ada dalam suatu konstitusi dijalankan dalam praktik ketatanegaraan. ${ }^{16}$

Untuk mendukung penelitian ini, peneliti menggunakan beberapa data sekunder (bahan hukum) yaitu: ${ }^{17}$ Pertama, bahan hukum primer atau bahan hukum yang utama meliputi: peraturan perundangundangan, konstitusi negara Amerika Serikat dan Korea Selatan, dan segala dokumen resmi yang memuat ketentuan hukum lainnya yang relevan dengan penelitian; Kedua, bahan hukum sekunder yang memberikan penjelasan terhadap bahan hukum primer meliputi: buku-buku, jurnal, artikel, hasil penelitian, dan bahan lainnya yang

15 Peter de Cruz, Comparative Law in a Changing World (London: Cavendish, 1999) at 18 .

16 Francois Venter, Constitutional Comparison: Japan, Germany, Canada E South Africa as Constitutional State (Cape Town: Juta \& CO Ltd, 2000) at 41-44.

17 Soekanto \& Mamuji, supra note 12. dalam Muhaimin, Metode Penelitian Hukum (Mataram: Mataram University Press, 2020) at 60-62. 
relevan dengan penelitian; dan Ketiga, bahan hukum tersier untuk memberikan petunjuk dan penjelasan terhadap bahan hukum primer maupun sekunder meliputi: kamus dan ensiklopedia.

Alur pikir yang digunakan oleh peneliti diantaranya: Pertama, pemikiran peneliti mengenai proses impeachment Presiden dan/atau Wakil Presiden Indonesia yang ditemukan dari bacaan literaturliteratur hukum tentang perbandingan mekanisme impeachment saat sebelum amendemen dengan setelah amendemen ketiga UUD NRI 1945; Kedua, pada praktiknya proses impeachment presiden yang terjadi di Indonesia saat sebelum dilakukannya amendemen ketiga UUD NRI 1945 menyalahi sistem pemerintahan Indonesia, selain itu di dalam literatur yang dibaca masih terdapat permasalahanpermasalahan hukum yang akan terjadi disamping dengan berlakunya proses mekanisme impeachment yang termaktub di dalam UUD NRI 1945 perubahan ketiga yaitu: apakah tepat disatukannya pelanggaran hukum baik itu pelanggaran hukum berat dan ringan (tercela) yang dilakukan oleh Presiden dan/atau Wakil Presiden yang menjadi alasan impeachment oleh DPR pada akhirnya diputuskan oleh MPR dalam hal ini sebagai unsur politik bukan kepada MK sebagai unsur hukum dan mengenai tata cara DPR dalam hal mengumpulkan bukti-bukti bahwa Presiden dan/atau Wakil Presiden melakukan pelanggaran hukum; Ketiga, peneliti membuat fokus penelitiannya kepada permasalahan efektif atau tidak bahwa keputusan impeachment berada di tangan MPR apabila Presiden dan/atau Wakil Presiden terbukti melakukan pelanggaran hukum baik pelanggaran hukum berat atau ringan (tercela); Keempat, peneliti mengumpulkan bahan-bahan hukum dan menentukan negaranegara yang menjadi objek perbandingan; Kelima, peneliti melakukan analisis dan interpretasi dari bahan-bahan hukum yang didapatkan; dan Keenam, hasil analisis dan interpretasi tersebut digunakan untuk dibuat kesimpulan penelitian. 


\section{MEKANISME DAN PRAKTIK PROSES IMPEACHMENT DI AMERIKA SERIKAT}

Dasar hukum dalam praktik impeachment di Amerika Serikat tertera pada Article I, Section 2, Clause 5 konstitusi Amerika Serikat yang berbunyi "The House of Representatives shall choose their Speaker and other Officers; and shall have the sole Power of Impeachment". Selain itu Article I, Section 3, Clause 6 menentukan peran senat dalam proses Impeachment, yakni "The Senate shall have the sole Power to try all Impeachments, When the President of the United States is tried, the Chief Justice shall preside: And no Person shall be convicted without the Concurrence of two-thirds of the Members present"18. Dua pasal tersebut menunjukan bahwa proses impeachment terhadap Presiden dan/atau Wakil Presiden Amerika Serikat yang melibatkan 2 (dua) lembaga negara yaitu Senate dan House of Representative, dari ketentuan tersebut, proses impeachment diawali dengan dakwaan dari House of Representative kepada Presiden ${ }^{19}$.

Senate dan House of Representative merupakan lembaga negara yang memiliki fungsi legislatif dalam struktur ketatanegaraan Amerika Serikat. Hal tersebut tercantum pada Pasal 1 Konstitusi Amerika Serikat yang berbunyi "All legislative Powers herein granted shall be vested in a Congress of the United States, which shall consist of a Senate and House of Representatives". Perbedaan kewenangan dari kedua lembaga tersebut adalah anggota Senate terdiri dari perwakilan negara bagian yang dipilih setiap enam tahun sekali dan setiap negara bagian hanya boleh memiliki dua orang ${ }^{20}$, sedangkan house of representatives terdiri dari anggota yang dipilih dari beberapa negara bagian yang dipilih

18 Lihat juga H Lowell Brown, High Crimes and Misdemeanors in Presidential Impeachment (Palgrave: Macmillan, 2010) at 36.

19 Lihat juga Peter C Hoffer \& NEH Hull, Impeachment in America, 1635-1805 (New Haven: Yale UP, 1984) at 46-47.

${ }^{20}$ Lihat Article 3 Konstitusi Amerika Serikat "The Senate of the United States shall be composed of two Senators from each State, [chosen by the Legislature thereof, ]* for six Years; and each Senator shall have one Vote." Lihat juga Koestler-Grack, Rachel A, House of Representatives, (Infobase Publishing: New York, 2007) at 22. 
setiap dua tahun sekali ${ }^{21}$, dalam house of representatives, semakin banyak populasi negara bagian maka akan semakin banyak pula wakil dari negara bagian tersebut. Hal tersebut juga didasarkan pada teori bahwa house of representatives merupakan political representation yang artinya mereka mewakili Individu dari masyarakat Amerika Serikat dan Senate merupakan territorial representation yang artinya mereka mewakili negara bagian tempat mereka dipilih. Perpaduan kedua representation tersebut dianggap mampu mewakili seluruh warga Amerika Serikat dalam parlemen. ${ }^{22}$

Proses pendakwaan terhadap perilaku Presiden dan/atau Wakil Presiden diawali dengan usulan impeachment dari beberapa anggota House of Representatives lalu dilakukan pembahasan untuk mendapat kesepakatan bersama pada sidang pleno House of Representatives, dan usulan tersebut tidak dapat lanjutkan apabila ditolak. Sebelum itu, House of Representative membentuk komite sebagai penyusun Articles of Impeachment, Articles tersebut berisikan beberapa alasan House of Representative dapat meng-impeach Presiden dan/atau Wakil Presiden. Setelah dilakukannya pemeriksaan terhadap Articles tersebut, Senat kemudian mengeluarkan putusan. Pengambilan putusan tersebut harus dihadiri setidaknya oleh $2 / 3$ anggota pada Sidang Senat. ${ }^{23}$

Article I, Section 3, Clause 7 menentukan bahwa "Judgment in Cases of Impeachment shall not extend further than to removal from Office, and disqualification to hold and enjoy any Office of honor, Trust or Profit under the United States; but the Party convicted shall nevertheless be liable and subject to Indictment, Trial, Judgment and Punishment, according to Law". Putusan Senat terkait impeachment hanya dapat berbentuk keputusan berupa dapat diberhentikan atau tidaknya Presiden dan/atau Wakil

${ }^{21}$ Lihat Article 2 Konstitusi Amerika Serikat "The House of Representatives shall be composed of Members chosen every second Year by the People of the several States, and the Electors in each State shall have the Qualifications requisite for Electors of the most numerous Branch of the State Legislature".

22 Andrew Rehfeld, Political Representation, Democratic Legitimacy, and Institutional Design (New York: Cambridge University Press, 2005) at 15.

23 Hoffer \& Hull, supra note 19. Lihat juga pada John Murphy, The Impeachment Process (New York: Infobase Publishing, 2007) at 38. 
Presiden. Senat tidak dapat memberikan putusan berupa sanksi pidana atau perdata, di samping itu pemberhentian oleh Senat tidak mengakibatkan Presiden dan/atau Wakil Presiden dapat bebas dari tanggung jawab lainnya (seperti dakwaan dan proses peradilan). Hal ini pun sejalan dengan Article II, Section 4 bahwa Presiden berhak mendapatkan penangguhan hukuman dan pengampunan atas perbuatan melawan hukum Amerika Serikat, kecuali dalam kasus impeachment ${ }^{24}$.

Lalu apa saja alasan yang dapat dipakai untuk mendakwa Presiden dan/atau Wakil Presiden Amerika Serikat? Article II Section 4 Konstitusi Amerika Serikat menentukan "The President, Vice President and Civil Officers of the United States, shall be removed from Office on Impeachment for, and Conviction of, Treason, Bribery, or other high Crimes and Misdemeanors" (melakukan pengkhianatan, suap, atau kejahatan ringan maupun berat lainnya) ${ }^{25}$.

Pada abad ke 17 dan 18, yang dimaksud dalam High crimes and misdemeanors adalah aktivitas korup ataupun kejahatan yang dilakukan oleh seseorang yang memiliki tugas khusus yang tidak dimiliki oleh masyarakat biasa. ${ }^{26}$ Namun, menjelang akhir tahun 1800-an, makna tersebut berubah menjadi segala bentuk maladministrasi dari institusi pemerintahan. ${ }^{27}$

Konsep mal-administrasi tersebut sempat menuai kontroversi di Amerika Serikat sebab banyak yang menganggap hanya tindakan kriminal saja yang menjadi alasan paling logis untuk impeachment, namun dalam federalist paper 65, Alexander Hamilton mengatakan hal

24 Ibid.

25 Brown, supra note 18.

26 Gary L McDowell, "High Crimes and Misdeamenors: Recovering the Intensions of the Founder" (1999) 67:1148 Geo Wash Int'1 L Rev. Lihat juga pada Jon Roland, "Meaning of High Crimes and Misdemeanors", (2012), online: Constitution Society<https://constitution.org/cmt/high_crimes.htm>.

27 US Judiciary Committee, "Constitutional Grounds for Presidential Impeachment: II. The Historical Origins of Impeachment B. The Intentions of the Framers", (2019), online: washingtonpost. 
tersebut bertentangan dengan kehendak para founding father dan praktik ketatanegaraan dalam sejarah Amerika Serikat, hal tersebut dikarenakan alasan pejabat publik dapat di impeach adalah ketika mereka menyalahgunaan kepercayaan publik yang telah mereka dapatkan, sehingga alasan kriminal saja tidaklah cukup untuk menjadi alasan dasar untuk melakukan impeachment. Maka wajar jenis pelanggaran hukum yang dilakukan oleh Presiden dan/atau Wakil Presiden dalam impeachment merupakan pelanggaran yang bersifat politis dan bukan bersifat kriminal, sebab yang diciderai dalam hal ini adalah kepercayaan publik $^{28}$. Maka dapat diambil kesimpulan, perilaku pencideraan keparcayaan publik dapat mencakup perilaku yang melanggar kewajiban yang seharusnya dilakukan oleh seorang pejabat terhadap negara, meskipun tindakan tersebut bukanlah tindakan kriminal dan tidak selalu merupakan pelanggaran hukum.

Tujuan impeachment di Amerika Serikat bukanlah untuk menjatuhkan hukuman atas perbuatan criminal yang dilakukan oleh seseorang. Sebaliknya, impeachment adalah alat perbaikan yang diharapkan dapat berfungsi secara efektif untuk mempertahankan pemerintahan yang konstitusional dengan meng-impeach individuindividu yang tidak layak untuk menjabat dalam pemerintahan. ${ }^{29}$ Kongres telah mengidentifikasi tiga jenis perilaku umum yang dapat menjadi dasar impeachment: ${ }^{30}$

1. Melakukan penyalahagunaan atau bertindak melebihi kekuasaan;

2. Perilaku yang tidak sesuai dengan fungsi dan tujuan dari instansi terkait; dan

28 Alexander Hamilton, The Federalist No.65, dalam Michael J Gerhardt, “Lessons of Impeachment History" (1999) 67:3 George Wash Law Rev 603-625 at 603.

29 Hoffer \& Hull, supra note 19. Lihat juga Staff of the Impeachment Inquiry House of Representatives, "Constitutional Grounds for Presidential Impeachment", (1974), online: judiciary.house.gov.

30 Staff of the Impeachment Inquiry House of Representatives, supra note 29. 
3. Menyalahgunakan jabatan untuk tujuan yang tidak patut atau untuk keuntungan pribadi.

Hal ini dapat dicontohkan dalam kasus impeachment presiden Richard Nixon, dimana tuduhan impeachment ditolak oleh komite kehakiman senat sebab alasan yang dijadikan dasar adalah Nixon melakukan penipuan pajak, dan alasan tersebut dianggap hanya terkait dengan perilaku pribadi Presiden, bukan penyalahgunaan wewenangnya sebagai Presiden. Meskipun pada akhirnya Nixon mengundurkan diri dari jabatannya sebagai presiden sebelum diadakannya pemungutan suara di Senat.

\section{a. Praktik Proses Impeachment di Amerika Serikat}

Mengenai kasus-kasus impeachment terhadap Presiden dan/atau Wakil Presiden Amerika Serikat, sepanjang sejarah, tiga Presiden Amerika Serikat telah dicoba untuk dilakukan impeachment, yakni di tahun 1868 ada Andrew Johnson, tahun 1998 ada Bill Clinton, dan 2019 ada Donald Trump. Ketiganya secara resmi diadili di Senat tetapi tidak ada yang berhasil.

\section{1) Impeachment Andrew Johnson}

Resolusi impeachment terhadap Andrew Johnson dikeluarkan pada 24 Februari 1868. Resolusi tersebut berisi 11 poin artikel alasan impeachment yang menyimpulkan kepada high crimes and misdemeanors ${ }^{31}$. Tuduhan utama terhadap Johnson adalah bahwa ia telah melanggar Tenure of Office Act, disahkan oleh Kongres pada Maret 1867. Tenure of Office Act merupakan Act yang disahkan oleh kongres pada tahun 1867 yang berisi pengaturan mengenai pembatasan kekuasaan presiden untuk memecat atau menghapus jabatan tertentu tanpa adanya persetujuan dari senat.

3111 poin artikel impeachment tersebut adalah berkaitan dengan Pelanggaran dan Konspirasi yang dilakukan oleh Presiden Andrew Johnson terhadap Edward Santon. Lebih lanjut lihat dalam James E Sefton, "The Impeachment of Andrew Johnson: A Century of Writing" (1968) 14:2 Civ War Hist 120-147 at 120 . 
Kisah Impeachment ini berawal dari kongres yang mengesahkan Tenure of Office Act, yang mana dalam salah satu ketentuannya mengharuskan presiden untuk meminta saran dan persetujuan Senat sebelum membebastugaskan atau memberhentikan setiap anggota kabinetnya. Namun dalam act tersebut terdapat pengecualian yakni mengizinkan presiden untuk memberhentikan pejabat secara langsung ketika Kongres tidak sedang masa sidang. Hal tersebut dimanfaatkan oleh Johnson untuk memecat Edwin M.Santon dari jabatannya sebagai secretary of war dan digantikan oleh Jenderal Ulysses S. Grant, hanya saja Senat tidak menyetujui keputusan Johnson tersebut. ${ }^{32}$

Setelah mendapat kabar ketidaksetujuan Senat, Grant mengundurkan diri dari jabatannya dan menyebabkan Johnson marah besar kepada Grant. Setelah itu Johnson harus mencari seseorang untuk menempati posisi secretary of war, posisi tersebut kembali diisi oleh Edwin M.Santon, seseorang yang sangat tidak disukai Johnson. Johnson tidak menyukai Santon dikarenakan Santon merupakan seseorang yang berasal dari Partai Republik sedangkan Johnson berasal dari Partai Demokrat. Setelah beberapa saat, Johnson akhirnya menunjuk Lorenzo Thomas, seorang mayor jenderal di Angkatan Darat, sebagai secretary of war sementara. Stanton yang tidak senang akan keputusan tersebut justru memerintahkan untuk menangkap Thomas atas tuduhan melanggar Tenure of Office Act, penunjukan Thomas juga menyebabkan lawan politik Johnson di kongres marah sebab sudah beberapa kali Johnson melanggar Tenure of Office Act. Selang tiga hari dari pemecatan Stanton, beberapa anggota House of Representatives dari partai Republik memulai upaya impeachment terhadap Johnson dengan klausa High crimes and misdemeanors yang poin utama nya adalah

32 Edmund G Ross, "History of the Impeachment of Andrew Johnson, President of The United States By The House Of Representatives and His Trial by The Senate for High Crimes and Misdemeanors in Office 1868", (2000), online: Public Library $<$ http://www.publiclibrary.uk/ebooks/47/98.pdf\&usg=ALkJrhg8v55GpXYZNIdWX6J38nl_mjYgD g>., at 105 . 
Removed Secretary of War Stanton before the Senate confirmed his successor, a violation of the Tenure of Office Act. ${ }^{33}$

Usulan Impeachment diterima oleh 126 anggota House of Representatives, dan 47 anggota menolak usulan impeachment tersebut.

\begin{tabular}{|l|l|l|l|}
\hline Suara & Republik & Demokrat & Jumlah \\
\hline Ya & 122 & 4 & 126 \\
\hline Tidak & 2 & 45 & 47 \\
\hline
\end{tabular}

Saat usulan Impeachment ini sudah sampai ke ranah Senat, yang saat itu terdiri dari 54 anggota yang mewakili 27 negara bagian, maka berdasarkan konstitusi AS dibutuhkan dua per tiga atau jika dijumlahkan membutuhkan 36 suara "Ya" dari senat agar Impeachment dapat berjalan. Namun hasilnya, hanya 35 orang dari senat yang menyetujui Impeachment, hanya kurang satu anggota. ${ }^{34}$

\begin{tabular}{|l|l|l|l|}
\hline Suara & Republik & Demokrat & Jumlah \\
\hline Ya & 35 & 0 & 35 \\
\hline Tidak & 10 & 9 & 19 \\
\hline
\end{tabular}

\section{2) Proses Impeachment Bill Clinton}

Proses Impeachment terhadap Bill Clinton dimulai pada 8 Oktober 1998 ketika House of Representatives menuduh Clinton melakukan High crimes and misdemeanors. Tuduhan tersebut berawal dari dugaan Clinton melakukan pelecehan seksual yang diajukan oleh Paula Jones $^{35}$. Hal tersebut menjadikan Clinton menjadi presiden kedua yang mengalami usaha pemakzulan setelah Andrew Johnson, dan dituduhkan dengan klausa yang sama seperti Andrew Johnson.

33 Ibid at 106.

34 Ibid at 107.

35 Keith E Whittington, “Bill Clinton Was No Andrew Johnson: Comparing Two Impeachments" (2000) 2:2 J Const Law 422-465 at 424. 
Kisah ini berawal pada tahun 1994 ketika Paula Jones, perempuan yang merupakan Gubernur Kansas pada saat itu menuduh Clinton melakukan pelecehan seksual kepadanya. Belum selesai kasusnya dengan Paula Jones, Clinton kembali mendapat skandal seksual dengan Monica Lewinsky, seorang pegawai perempuan di Kementerian Pertahanan Amerika Serikat. Banyak yang menduga, terutama pers, bahwasanya Clinton melakukan sumpah palsu pada dua persidangan yang menyangkut dirinya tersebut ${ }^{36}$.

Meskipun Clinton secara tegas menyangkal hal-hal tersebut, Fraksi Republik pada House of Representatives melayangkan tuduhan Impeachment kepada Clinton. Impeachment didasarkan atas empat argumentasi tuduhan, yakni sumpah palsu kasus Paula Jones dan Monica Lewinsky, kasus pelecehan seksual, Obstruction of Justice ${ }^{37}$, dan Abuse of Power. Mayoritas anggota House of Representatives yang dikuasai partai Republik pun menyetujui dua dari empat usulan Impeachment tersebut. ${ }^{38}$

\section{Tuduhan Sumpah Palsu}

\begin{tabular}{|l|l|l|l|l|}
\hline Suara & Republik & Demokrat & Independen & Jumlah \\
\hline Ya & 223 & 5 & 0 & $\mathbf{2 2 8}$ \\
\hline Tidak & 5 & 200 & 1 & 206 \\
\hline
\end{tabular}

\section{Tuduhan Pelecehan Seksual}

36 Sumpah Palsu yang dilakukan oleh Bill Clinton adalah sumpah palsu yang diucapkan pada proses peradilan dimana dia dituduh melakukan pelecehan seksual.

37 Obstruction of Justice yang dimaksud disini adalah penghalangan proses peradilan ketika Bill Clinton diduga melakukan pelecehan seksual.

38 Andrew Glass, "House Votes to Impeach Clinton", (2017), online: Politicio $<$ https://www.politico.com/story/2017/10/08/house-votes-to-impeach-clintonoct-8-1998>. Lihat juga pada Morris Fiorina, Samuel Abrams \& Jeremy Pope, “The 2000 U.S. Presidential Election: Can Retrospective Voting Be Saved?" (2003) 33:2 Br J Polit Sci 163-187 at 163. 


\begin{tabular}{|l|l|l|l|l|}
\hline Suara & Republik & Demokrat & Independen & Jumlah \\
\hline Ya & 200 & 5 & 0 & 205 \\
\hline Tidak & 28 & 200 & 1 & $\mathbf{2 2 9}$ \\
\hline
\end{tabular}

Obstruction of Justice

\begin{tabular}{|l|l|l|l|l|}
\hline Suara & Republik & Demokrat & Independen & Jumlah \\
\hline Ya & 216 & 5 & 0 & $\mathbf{2 2 1}$ \\
\hline Tidak & 12 & 199 & 1 & 212 \\
\hline
\end{tabular}

Abuse of Power

\begin{tabular}{|l|l|l|l|l|}
\hline Suara & Republik & Demokrat & Independen & Jumlah \\
\hline Ya & 147 & 1 & 0 & 148 \\
\hline Tidak & 81 & 203 & 1 & $\mathbf{2 8 5}$ \\
\hline
\end{tabular}

Maka dari itu, tuduhan impeachment yang lolos menuju Senat hanyalah dua, yakni tuduhan melakukan sumpah palsu dan obstruction of justice. Sidang dalam Senat dipimpin oleh Ketua Mahkamah Agung Amerika Serikat William Rehnquist. Total anggota Senat pada masa itu adalah 100 orang, maka membutuhkan setidaknya 67 suara "Ya" untuk membuat Bill Clinton dikenakan impeachment, namun suara senat tidak mencapai dua per tiga. ${ }^{39}$

\section{Tuduhan Sumpah Palsu}

\begin{tabular}{|l|l|l|l|}
\hline Suara & Republik & Demokrat & Jumlah \\
\hline Ya & 45 & 0 & 45 \\
\hline Tidak & 10 & 45 & 55 \\
\hline
\end{tabular}

39 Peter Baker, "The Senate Acquits President Clinton", (1999), online: washingtonpost. 


\section{Tuduhan Obstriction of Justice}

\begin{tabular}{|l|l|l|l|}
\hline Suara & Republik & Demokrat & Jumlah \\
\hline Ya & 50 & 0 & 50 \\
\hline Tidak & 5 & 45 & 50 \\
\hline
\end{tabular}

\section{3) Proses Impeachment Donald Trump}

Tuduhan impeachment dilayangkan terhadap Donald Trump diawali dengan dugaan Trump meminta campur tangan asing dalam Pemilihan Umum Amerika Serikat 2020 agar dia terpilih kembali dan dianggap melakukan penghalangan penyelidikan atas kasusnya. Diawali dengan skandal antara Trump dan Ukraina, Trump diduga meminta keterlibatan Ukraina untuk merusak citra dari lawan politiknya yakni Joe Biden. Hal tersebut membuat Trump dilayangkan tuduhan meminta campur tangan asing untuk membuatnya terpilih kembali pada Pemilu tahun 2020.

House of Representative akhirnya melayangkan dua tuduhan pelanggaran kepada Trump, yakni abuse of power, karena Trump menyalahgunakan kekuasannya dengan mencoba mempengaruhi Presiden Ukraina untuk kepentingan pribadi, dan Obstruction of Congress atas upaya Trump untuk menghalangi penyidikan kongres atas kasusnya. Akhirnya House of Representative menyetujui dua tuduhan tersebut untuk dibawakan ke Senat. ${ }^{40}$

Abuse of Power

\begin{tabular}{|l|l|l|l|}
\hline Suara & Republik & Demokrat & Jumlah \\
\hline Ya & 0 & 229 & 229 \\
\hline Tidak & 195 & 2 & 197 \\
\hline
\end{tabular}

40 Nicholas Fandos, "Trump Acquitted of Two Impeachment Charges in Near Party-Line Vote", (2020), online: nytimes. 
Obstraction of Congress

\begin{tabular}{|l|l|l|l|}
\hline Suara & Republik & Demokrat & Jumlah \\
\hline Ya & 0 & 228 & $\mathbf{2 2 8}$ \\
\hline Tidak & 195 & 1 & 195 \\
\hline
\end{tabular}

Dua tuduhan tersebut berhasil dibawa ke Senat yang dikuasai oleh partai Republik, dikarenakan Konstitusi AS menentukan 2/3 dari anggota kongres harus menyetujui impeachment ${ }^{41}$. Maka diperlukan 67 orang yang memilih "Ya", dan hasilnya Senat menolak upaya impeachment. ${ }^{42}$

\section{Abuse of Power}

\begin{tabular}{|l|l|l|l|}
\hline Suara & Republik & Demokrat & Jumlah \\
\hline Ya & 1 & 47 & 48 \\
\hline Tidak & 52 & 0 & $\mathbf{5 2}$ \\
\hline
\end{tabular}

\section{Obstraction of Congress}

\begin{tabular}{|l|l|l|l|}
\hline Suara & Republik & Demokrat & Jumlah \\
\hline Ya & 0 & 47 & 47 \\
\hline Tidak & 53 & 0 & 53 \\
\hline
\end{tabular}

${ }^{41}$ Lihat Section 3 Paragraph 6 Konstitusi Amerika Serikat "The Senate shall have the sole Power to try all Impeachments. When sitting for that Purpose, they shall be on Oath or Affirmation. When the President of the United States is tried, the Chief Justice shall preside: And no Person shall be convicted without the Concurrence of two thirds of the Members present."

42 Fandos, supra note 40. 


\section{MEKANISME DAN PRAKTIK PROSES IMPEACHMENT DI KOREA SELATAN}

\section{a. Mekanisme Proses Impeachment di Korea Selatan}

Perlu diketahui terlebih dahulu, bahwasanya Korea Selatan merupakan negara yang tidak menganut sistem pemerintahan presidensiil murni, namun sistem semi presidensiil. Hal ini dapat terlihat dalam Pasal 87 Konstitusi Korea Selatan yang mengatakan "The members of the State Council shall be appointed by the President on the recommendation of the Prime Minister. The members of the State Council shall assist the President in the conduct of State affairs and, as constituents of the State Council, shall deliberate on State affairs. The Prime Minister may recommend to the President the removal of a member of the State Council from office. No member of the military shall be appointed a member of the State Council unless he is retired from active duty". Dari pasal tersebut menunjukkan bahwa seorang Presiden memiliki Perdana Menteri yang berfungsi sebagai pemberi rekomendasi, rekomendasi ini berfungsi untuk keanggotaan State Council, selain itu dapat memberi rekomendasi pemberhentian State Council (dalam hal ini Presiden dan Wakil Presiden menjadi ketua dan wakil ketua State Council karena State Council terdiri dari Presiden, Perdana Menteri dan anggota lainnya).

Impeachment di Korea Selatan diatur dalam Pasal 65 Ayat (1) Konstitusi Korea Selatan menunjukan bahwa objek Impeachment di Korea Selatan bukan hanya Presiden dan/atau Wakil Presiden, namun juga Hakim, Hakim Konstitusi, anggota komite pemilihan umum, anggota inspeksi dan audit, dan jabatan publik lainnya yang dibentuk oleh undang-undang.

Selanjutnya Pasal 111 Konstitusi Korea Selatan "The Constitution Court shall adjudicate the following matters: The constitutionality of a law upon the request of the courts, Impeachment, Dissolution of a political party, Disputes about the jurisdictions between State agencies, between State agencies and local governments and between local governments and Petitions relating to the Constitution as prescribed by law". Pasal tersebut menjelaskan bahwa MK sebagai lembaga yang memiliki kewenangan 
untuk mengadili perkara Impeachment yang diajukan oleh National Assembly. National Assembly merupakan satu-satunya lembaga legislatif yang ada dalam struktur ketatanegaraan Korea Selatan ${ }^{43}$. Kewenangan dari National Assembly ini yakni mengajukan dan membahas rancangan undang-undang ${ }^{44}$ membahas dan memutuskan anggaran negara ${ }^{45}$, dan mengusulkan impeachment ${ }^{46}$.

Dua pasal tersebut menjelaskan bahwa hanya ada dua lembaga negara di Korea Selatan yang terlibat dalam proses Impeachment, yakni National Assembly dan MK. Mekanisme impeachment di Korea Selatan diawali dari adanya usulan memberhentikan Presiden oleh National Assembly kepada Constitutional Court. Kemudian, Constitutional Court dapat langsung memberhentikan Presiden tanpa harus dikembalikan kepada lembaga legislatif, mengingat bahwa Korea Selatan merupakan unicameral (satu kamar) yaitu National Assembly, sehingga legislatif tidak memiliki kekuatan yang besar dalam memutus pemberhentian Presiden.

Prosedur agar Presiden dapat dimakzulkan dalam proses impeachment, terdapat dalam Pasal 65 Ayat (2) Konstitusi Korea Selatan yakni syarat dimulainya upaya impeachment oleh National Assembly harus diajukan oleh lebih dari 1/2 anggota dan disetujui oleh 2/3 dari jumlah anggota National Assembly. Ketika National Assembly sepakat untuk melanjutkan ke MK, maka Mahkamah wajib mengadili tuduhan Impeachment tersebut. Pasal 113 Ayat (1)

43 Lihat Pasal 40 Konstitusi Korea Selatan "The legislative power shall be vested in the National Assembly".

44 Lihat Pasal 52 Konstitusi Korea Selatan "Bills may be introduced by members of the National Assembly or by the Executive".

45 Lihat Pasal 54 Ayat (1) Konstitusi Korea Selatan "The National Assembly shall deliberate and decide upon the national budget bill".

46 Lihat Pasal 65 Ayat (1) Konstitusi Korea Selatan "In case the President, the Prime Minister, members of the State Council, heads of Executive Ministries, judges of the Constitution Court, judges, members of the Central Election Management Committee, members of the Board of Audit and Inspection, and other public officials designated by law have violated the Constitution or other laws in the performance of official duties, the National Assembly may pass motions for their impeachment". 
Konstitusi Korea Selatan mengatur "When the Constitution Court makes a decision on the unconstitutionality of a law, impeachment, dissolution of a political party or a petition relating to the Constitution, the concurrence of six adjudicators or more shall be required". Maka tuduhan Impeachment akan menjadi sah jika enam hakim konstitusi menyetujui tuduhan Impeachment yang dilayangkan oleh National Assembly.

\section{b. Praktik Proses Impeachment di Amerika Serikat 1) Proses Impeachment Roh Moo Hyun}

Resolusi Proses Impeachment kepada Roh Moo Hyun dimulai ketika ada pertentangan antara Roh dengan partai nium Democratic Party (MDP) yang mengusungnya sebagai presiden. Pada pertengahan masa jabatan Roh, terdapat pertentangan antara Roh dan MDP. Pertentangan tersebut membuat Roh membentuk partai barunya sendiri, yakni Partai Uri. MDP yang kecewa dengan tindakan Roh, langsung membuat koalisi anti Roh bersama dengan partai Grand National Party (GNP), dan saat itu partai MDP dan GNP merupakan partai yang dominan di National Assembly hingga dapat membentuk absolut majority di dalam National Assembly hingga mencapai 272 anggota atau sekitar 2/3 dari total anggota National Assembly.

Saat mendekati Pemilu Korea Selatan, Partai Uri langsung menjadi partai peserta pemilu di Korea Selatan untuk menempati National Assembly. Pada proses kampanye Pemilu tersebut, Roh Moo Hyun melakukan promosi kepada publik secara terbuka untuk memilih Partai Uri. National Assembly yang dikuasai oleh koalisi anti Roh dari kalangan GNP dan MDP, menganggap hal yang dilakukan oleh Roh adalah pelanggaran hukum dan memaksa Roh untuk meminta maaf di hadapan publik. Roh menganggap hal tersebut tidak melawan hukum dan menolak untuk meminta maaf. ${ }^{47}$

47 Youngjae Lee, "Law, Politics, and Impeachment: The Impeachment of Roh Moo-hyun from a Comparative Constitutional Perspective" (2005) 53:2 Am J Comp Law 403-432 at 415, Lihat juga pada News Hankookicom, "Motion for Impeach Roh Moo Hyun", (2004), online: Hankooki <https://news.naver.com/main/read.nhn\%3Foid\%3D001\%26aid\%3D00005911 89\&usg=ALkJrhgH3bW6UVO5lelOfVghbfUlArFWag>. 
National Assembly yang murka akan keputusan Roh memilih jalan impeachment untuk menghukum Roh atas perbuatannya, mereka menganggap Roh telah melanggar Election for Public Office and Election Malpractice Prevention Act, dalam Pasal 9 Act menentukan bahwasa "public officials and others who must remain politically neutral shall not improperly influence elections or otherwise engage in behaviors that would influence election results", dan secara absolut tuduhan terus disetujui oleh National Assembly untuk diteruskan ke MK ${ }^{48}$.

Namun pada 14 Mei 2004, MK menolak tuduhan Impeachment tersebut, meskipun dalam amar putusannya MK mengatakan sependapat dengan National Assembly atas tuduhan melawan hukum yang dilakukan oleh Roh. Hanya saja MK melakukan interpretasi konstitusi bahwa yang dilarang oleh Konstitusi adalah perbuatan melawan hukum yang dapat menciderai "free and democratic basic order" (chayuminjujok kibonjilso). Hal-hal yang termasuk pencideraan tersebut berupa menerima suap, korupsi, penggelapan, penyalahgunaan wewenang yang dapat mengganggu cabang kekuasaan lain, kejahatan terhadap kemanusiaan, penindasan warga sipil, dan memanipulasi hasil pemilu ${ }^{49}$.

Atas dasar tafsir konstitusi yang dilakukan oleh $\mathrm{MK}$, maka Mahkamah berpendapat bahwa pelanggaran hukum yang dilakukan oleh Roh tidak cukup kuat untuk memaksa Roh turun dari jabatannya sebagai Presiden. Putusan inipun didukung oleh mayoritas warga Korea Selatan yang tidak sepakat atas usaha Impeachment yang dilakukan oleh National Assembly.

\section{2) Praktik Proses Impeachment Park Geun Hye}

Usaha Impeachment terhadap Park Geun Hye diawali dengan skandal terkait dengan Choi Soon Sil yang tidak memiliki posisi resmi di pemerintahan. Permasalahan mulai muncul ketika Park mulai menggunakan Choi dalam pemerintahan dan juga kehidupan

48 "Fission, Fusion, Reform And Failure In South Korean Politics: Roh MooHyun's Administration" in Korea Yearb 2008 (Leiden: Brill, 2008) at 73.

49 Ibid. 
pribadinya. Banyak juga dugaan pada saat itu, Choi banyak memengaruhi keputusan kebijakan dari Park termasuk membuatkan setiap pidato Park. Tak hanya itu, beberapa media juga melaporkan Presiden Park, Choi, dan beberapa staff senior kepresidenan seperti Ahn Jong Bum dan Jeong Ho Sung yang diduga menggunakan pengaruh mereka untuk memeras media Korea Chaebols sebesar 77,4 Milliar Won. Pada 25 Oktober 2016, Park meminta maaf kepada publik karena telah melibatkan Choi Soon Sil dalam setiap pengambilan kebijakan dan membuat setiap pidato Park. ${ }^{50}$

Dimulai pada 26 Oktober 2016, banyak sekali demonstrasi yang menuntut Presiden Park untuk mundur. Tiga hari kemudian, dia memecat pembantu utamanya termasuk kepala staf Kim Ki-choon dan dua anggota kabinet dan berusaha mengganti perdana menteri Hwang Kyo-ahn dengan Kim Byong-joon, asisten mantan presiden Roh Moo-hyun, tetapi ditolak oleh National Assembly. ${ }^{51}$

Tanggal 31 Oktober, Choi Soon Sil ditangkap oleh kejaksaan dan didakwa dengan penyalahgunaan kekuasaan dan penipuan pada 20 November. Park membuat permintaan maaf kedua pada 4 November, berjanji untuk bertanggung jawab jika dia dinyatakan bersalah, dan permintaan maaf ketiga pada 29 November. Protes di seluruh Korea Selatan dimulai pada 26 Oktober dengan elektabilitas Park turun menjadi 4\%, dan menurut survei, pada 9 Desember $78 \%$ warga Korea Selatan mendukung impeachment terhadap Park. Hingga akhirnya pada 9 Desember 2016, National Assembly sepakat untuk melayangkan Impeachment kepada Park dengan total 234 dari 300 anggota National Assembly menyetujui tuduhan penyalahgunaan

50 Sung D Hahm \& Uk Heo, "The First Female President in South Korea: Park Geun-hye's Leadership and South Korean Democracy" (2017) 53:5 Journal of Asian and African Studies 1-17. Lihat juga BBC, "South Korea's presidential scandal", (2018), online: BBC .co <https://www.bbc.co.uk/news/world-asia37971085\&usg=ALkJrhgRROTREHr0vR5m2O41XzaDUz17aA>.

51 Karoliina Piispa, Scandals, Shamans, and Samsung: framing analysis of media coverage on the Choi Soon-sil Gate University of Helsinki, 2018) [unpublished]. 
kekuasaan yang dilakukan oleh Park sehingga tuduhan Impeachment menjadi sah. ${ }^{52}$

Pada saat persidangan di MK, terbukalah fakta bahwa terdapat kolusi antara Park dan Choi untuk memaksa Samsung Group memberikan suap kepada mereka dan melakukannya juga ke lebih dari 9000 artis, penulis, dan pemain film professional dengan alasan bantuan sosial. Fakta-fakta tersebut dibuka untuk memperkuat argumentasi bahwa Presiden Park telah melakukan penyalahgunaan kekuasaan. Hingga akhirnya pada tanggal 10 Maret 2017 MK mengeluarkan putusan menyetujui Impeachment yang diajukan oleh National Assembly dengan argumentasi hal yang dilakukan oleh Presiden Park merupakan bagian dari menciderai "free and democratic basic order" (chayuminjujok kibonjilso), yakni pada poin penindasan terhadap warga sipil. ${ }^{53}$

\section{USULAN REFORMULASI MEKANISME IMPEACHMENT DI INDONESIA}

\section{a. Mekanisme Proses Impeachment di Indonesia}

Berdasarkan Pasal 7A UUD NRI 1945 mengatur beberapa alasan khusus untuk dapat melakukan impeachment terhadap Presiden dan/atau Wakil Presiden diantaranya telah terbukti melakukan pelanggaran hukum berupa pengkhianatan terhadap negara, korupsi, penyuapan, tindak pidana berat lainnya, atau perbuatan tercela maupun apabila terbukti tidak lagi memenuhi syarat sebagai Presiden dan/atau Wakil Presiden.

Sejalan dengan yang telah dijelaskan sebelumnya bahwa impeachment merupakan peradilan yang kental akan unsur politis, tidak menutupkemungkinan dapat disalahgunakan oleh legislating (DPR) sebagai lembaga yang dapat mengajukan dakwaan impeachment hanya dengan landasan suka atau tidak suka terhadap Presiden

52 The Independent, "South Korean opposition parties introduce bill to impeach scandal-hit President Park Geun-hye", (2016), online: independent.

53 Korea Herald, "Park Geun-hye Impeached", (2016), online: koreaherald. 
dan/atau Wakil Presiden. Maka hadirnya MK untuk menghindari penyalahgunaan mekanisme impeachment oleh DPR agar tetap sejalan dengan ketentuan-ketentuan yang diatur dalam konstitusi.

Di Indonesia, ada 3 (tiga) lembaga negara yang terlibat dalam proses impeachment yaitu DPR, MK dan MPR. ${ }^{54}$ Proses impeachment di Indonesia diawali pendapat dari DPR bahwa Presiden dan/atau Wakil Presiden telah melanggar hukum atau tidak lagi memenuhi syarat sebagai Presiden dan/atau Wakil Presiden. Pendapat DPR tersebut sering disebut dengan hak menyatakan pendapat yang berkaitan dengan fungsi pengawasan DPR. ${ }^{55}$ Sejalan dengan hal tersebut, pada Pasal 79 ayat (4) huruf c Undang-Undang Nomor 13 Tahun 2019 tentang Perubahan Ketiga atas Undang-Undang Nomor 17 Tahun 2014 tentang MPR, DPR, DPD dan DPRD (UU No. 13 Tahun 2019) menentukan bahwa hak menyatakan pendapat dapat digunakan oleh DPR dalam proses impeachment Presiden dan/atau Wakil Presiden.

Hak DPR tersebut cukup diusulkan oleh 25 (dua puluh lima) anggota DPR, ${ }^{56}$ namun berdasarkan Pasal 7B ayat (3) UUD NRI 1945 hak tersebut dapat menjadi hak menyatakan pendapat DPR bila telah ada persetujuan pada rapat paripurna yang dihadiri $2 / 3$ dari jumlah anggota DPR dengan keputusannya paling sedikit 2/3 dari jumlah anggota DPR yang hadir. Sejalan dengan hal itu, dalam Pasal 210 ayat (3) UU No. 13 Tahun 2019 menentukan:

"Usul sebagaimana dimaksud pada ayat (1) menjadi hak menyatakan pendapat DPR apabila mendapatkan persetujuan dari rapat paripurna DPR yang dihadiri paling sedikit 2/3 (dua per tiga) dari jumlah anggota DPR dan keputusan diambil dengan persetujuan paling sedikit 2/3 dari jumlah

54 Lihat Pasal 7B Undang-Undang Dasar Negara Republik Indonesia Tahun 1945.

55 Pasal 20A ayat (2).

56 Pasal 210 ayat (1) UU No. 13 Tahun 2019 tentang Perubahan Ketiga atas Undang-Undang Nomor 17 Tahun 2014 tentang Majelis Permusyawaratan Rakyat, Dewan Perwakilan Rakyat, Dewan Perwakilan Daerah, dan Dewan Perwakilan Rakyat Daerah. 
anggota DPR dan eputusan diambil dengan persetujuan paling sedikit 2/3 dari jumlah anggota DPR yang hadir."

Ketika keputusan rapat paripurna sepakat untuk menggunakan hak menyatakan pendapat, DPR dapat membentuk panitia khusus. ${ }^{57}$ Panitia khusus nantinya akan mencari serta mengumpulkan buktibukti untuk mendukung pendapatnya, dalam hal ini panitia khusus memiliki waktu selama 60 (enam puluh) hari sejak terbentuk. ${ }^{58}$ Setelah mengumpulkan bukti-bukti, panitia khusus harus menyampaikan laporan tersebut di rapat paripurna ${ }^{59}$ yang dihadiri 2/3 anggota DPR. Dalam hal ini peserta rapat paripurna dapat menerima atau menolak laporan tersebut. Laporan dapat dilanjutkan ke MK dengan syarat harus disetujui oleh 2/3 anggota yang hadir, ${ }^{60}$ apabila tidak memenuhi ketentuan (ditolak) maka hak menyatakan pendapat tidak dapat diajukan kembali. ${ }^{61}$

Ketentuan tersebut menggambarkan bahwa peran DPR sangatlah penting dalam melakukan impeachment terhadap Presiden dan/atau Wakil Presiden, karena berawal dari hak yang dimiliki oleh DPR sendiri. Dengan keadaan tersebut, tidak dapat dipungkiri bahwa kekuatan politik sangat menentukan Presiden dan/atau Wakil Presiden dapat dilkukan impeachment atau tidak.

Setelah DPR secara mayoritas sepakat dengan laporan yang diberikan oleh panitia khusus, selanjutnya DPR dapat menyampaikan keputusan tersebut ke MK untuk memperoleh putusan secara hukum. Peranan MK sebagai lembaga yang mengadili pendapat DPR dalam proses impeachment. Forum MK ini merupakan forum hukum, kemudian Hamdan Zoelva menyatakan:62 "Forum pemakzulan di MK dimaksudkan untuk melindungi tegaknya prinsip-prinsip negara hukum yang menghormati prinsip-prinsip negara

\footnotetext{
57 Pasal 212 ayat (2).

58 Pasal 213 ayat (1).

59 Pasal 213 ayat (2).

60 Pasal 214 ayat (2).

61 Pasal 214 ayat (3).

62 Zoelva, supra note 1.
} 
hukum, antara lain prinsip due process of law, prinsip equality before the law serta prinsip peradilan yang imparsial dalam memakzulkan Presiden. Proses ini juga menjamin tegaknya prinsip-prinsip negara demokrasi konstitusional modern yang menghormati prinsip pengaturan oleh mayoritas tetapi melindungi hak-hak minoritas. Presiden tidak harus selalu kalah oleh kekuatan mayoritas yang mendukung pemakzulan, karena Presiden memiliki hak konstitutusional yang dijamin oleh undang-undang dasar untuk membela dirinya berdasar atas prinsip hukum yang adil dan peradilan ynag imparsial."

Berdasarkan Pasal 24C ayat (2) UUD NRI 1945, MK wajib memberi putusan atas pendapat DPR terhadap Presiden dan/atau Wakil Presiden dengan jangka waktu pemeriksaan paling lama 90 hari, pada kesempatan yang sama Presiden dan/atau Wakil Presiden diberikan hak untuk membela dan/atau membantah pendapat DPR. Pada hasil akhir, putusan MK dapat berupa terbukti atau tidaknya pendapat DPR, ketika pendapat tersebut tidak tersebukti maka proses impeachment harus diberhentikan segera, namun ketika putusan MK terbukti, DPR harus melakukan sidang paripurna yang dihadiri 2/3 anggota dan disepakati oleh $2 / 3$ anggota yang hadir untuk dilanjutkan proses impeachment ke MPR.

Ketika MPR telah menerima usulan DPR, MPR wajb mengadakan sidang pemberhentian Presiden dan/atau Wakil Presiden dalam waktu paling lama 30 hari setelah menerima usul dari DPR tersebut. Dalam hal ini, proses impeachment di MPR termasuk forum politik karena tidak harus mengikuti putusan MK. Dalam memutus usulan DPR, MPR wajib mengadakan rapat paripurna dengan dihadiri 3/4 anggota dengan persetujuan 2/3 anggota yang hadir, sebelum MPR memutus usulan DPR, Presiden dan/atau Wakil Presiden dapat memberi penjelasan di forum tersebut atas usulan impeachment dari DPR. Keputusan MPR bersifat final dan mengikat serta tidak dapat dilakukan banding atau dibatalkan oleh pengadilan. Dengan demikian, DPR berkedudukan sebagai lembaga penuntut, sedangkan MK merupakan lembaga penengah (pemutus secara yuridis 
pendapat DPR) dan MPR merupakan lembaga pemutus akhir (secara politik).

\section{b. Mekanisme Impeachment Presiden dan Wakil Presiden yang Efektif untuk diterapkan di Indonesia}

Jika dilihat pada umumnya, terdapat dua jenis mekanisme impeachment yang dipakai oleh negara-negara presidensiil, yakni melibatkan atau tidak melibatkan lembaga peradilan. ${ }^{63}$ Indonesia dan Korea Selatan melibatkan lembaga peradilan untuk melaksanakan impeachment dinegaranya, sedangkan Amerika Serikat hanya melibatkan lembaga perwakilan saja untuk melaksanakan impeachment.

Sebagaimana telah dipaparkan sebelumnya, salah satu kasus impeachment yang pernah terjadi di Amerika Serikat adalah usaha impeachment terhadap Bill Clinton. Selama usaha impeachment terhadap Clinton berjalan, pertanyaan yang selalu muncul adalah apakah kesalahan yang dilakukan Clinton cukup fatal sehingga mengharuskan dia turun jabatan sebagai presiden? Selama proses tersebut, semua orang bertanya-tanya, sejauh mana batasan high Crimes and Misdemeanors yang dimaksud oleh Konstitusi? Dibebaskannya Clinton dari tuduhan impeachment di Senat tidak membuat arti dari high Crimes and Misdemeanors menjadi jelas dan putusan Senat tersebut tidak dapat dijadikan sebagai presedence di kasus impeachment selanjutnya yang menyangkut klausa high Crimes and Misdemeanors. ${ }^{64}$ Sehingga alasan senat untuk membebaskan presiden dari tuduhan impeachment akan selalu menjadi putusan politis dan satu-satunya rasionalisasi dari putusan tersebut adalah voting menunjukkan bahwa dia tidak bersalah.

Hal tersebut berbeda dengan Korea Selatan yang melibatkan lembaga peradilan dalam proses mekanisme impeachment dimana

63 Edi Prabowo, "Mekanisme Pemakzulan (Impeachment) Presiden: Studi Perbandingan Negara Indonesia dan Brasil" (2020) 1:2 J Indones Law 119-144 at $123-125$.

64 Cass R Sunstein, "Impeaching the President" (1998) 147:2 University of Pennsylvania Law Review 279-315 at 279. 
MK selalu memberikan argumentasi hukum dalam setiap keputusannya yang menentukan ter-impeach atau tidaknya seorang presiden yang sedang dikenakan usaha impeachment. Dalam kasus impeachment Roh Moo Hyun, MK melakukan interpretasi konstitusi bahwasanya yang dilarang oleh Konstitusi adalah perbuatan melawan hukum yang dapat menciderai "free and democratic basic order" (chayuminjujok kibonjilso). Hal-hal yang termasuk pencideraan tersebut diantaranya: menerima suap, korupsi, penggelapan, penyalahgunaan wewenang yang dapat mengganggu cabang kekuasaan lain, kejahatan terhadap kemanusiaan, penindasan warga sipil, dan yang terakhir adalah memanipulasi hasil pemilihan umum. Argumentasi itu pun selanjutnya dipakai kembali dalam memutuskan perkara impeachment Park Geun Hye.

Kemurnian keterlibatan unsur politik dalam mekanisme impeachment di Amerika Serikat membuat permasalahan yang sama dari impeachment terus berulang, yakni sejauh mana high Crimes and Misdemeanors dapat menjatuhkan presiden dari jabatannya? Gerald Ford, seorang anggota House of Representatives pada masa impeachment Bill Clinton menegaskan bahwa alasan seorang presiden dimakzulkan adalah persetujuan 2/3 dari anggota Senat, sehingga tafsir tersebut hanyalah milik $2 / 3$ anggota Senat yang ada pada saat itu. Pernyataan Ford tersebut banyak dikritik karena membuat anggota kongres memiliki kekuatan yang tidak terbatas yang bisa dimanfaatkan untuk alasan politis semata. Orang yang paling keras mengkritik pendapat tersebut adalah Raoul Berger, ia menganggap terkadang politik dapat membuat manusia seperti binatang, maka jika itu terjadi, apa jaminannya bahwa kongres akan mengartikan Crimes and Misdemeanors sesuai dengan apa yang kerangka konstitusi ataupun apa yang founding fathers inginkan?

Permasalahan mengenai impeachment merupakan gesekan yang sangat kuat antara hukum dan politik. Akhil Amar berpendapat impeachment dapat dideskripsikan sebagai "sensibly political as well as 
legal". ${ }^{65}$ Richard Posner mendeskripsikan impeachment sebagai "no Presidential impeachment can fail to be suffused with politics, but argues that popular justice and legal justice should not be confused". ${ }^{66}$ Dari pendeskripsian tersebut dapat disimpulkan bahwa harus ada jalur yang menghubungkan antara hukum dan politik dalam proses impeachment presiden, hal tersebut harus dilakukan agar impeachment tidak sepenuhnya murni unsur politik ${ }^{67}$.

Pelibatan peradilan ke dalam proses impeachment dapat disimpulkan merupakan implementasi dari tujuan proses pemakzulan untuk melindungi Konstitusi dan untuk mencegah penyalahgunaan kekuasaan oleh presiden. Dengan menyediakan mekanisme untuk pemakzulan, maka jelas bahwa konstitusi membuat tidak ada yang diatas hukum dan membuktikan bangsa yang menganut konstitusionalisme berkomitmen terhadap supremasi hukum. Hal tersebut menimbulkan arti bahwa proses pemakzulan adalah proses hukum, bukan politik, dan bahwa seorang Presiden dapat dimakzulkan hanya dengan alasan hukum. ${ }^{68}$ Maka dari itu, efektifitas pelibatan lembaga peradilan dalam proses impeachment terletak pada terjaminnya presiden yang akan dijatuhkan melalui impeachment memang terbukti melanggar hukum sebagaimana diatur dalam konstitusi, sebab konstitusi Amerika Serikat atau Korea

65 Akhil R Amar, “On Impeaching Presidents” (1999) 28:2 Hofstra Law Review 291-341 at 298.

66 Richard Posner, An Affair of State: The Investigation, Impeachment, and Trial of President Clinton (Harvard: Harvard University Press, 1999) at 130.

67 Bandingkan dengan Pengertian Impeachment menurut Raoul Berger, bahwa Impeachment merupakan suatu konsekuensi yang harus ditempuh dalam sistem presidensiil dikarenakan dalam sistem tersebut, presiden tidak bisa dengan mudah dijatuhkan atas alasan kebijakan nya yang buruk ataupun tidak popular, sehingga fokus dari Impeachment haruslah pelanggaran hukum. Lihat Raoul Berger, Impeachment, The Constitutional Problems (United States of America: Bantam Books, 1974) at 354.

68 Jeong-ho Roh, "Crafting and Consolidating Constitutional Democracy in Korea", online: Korea's Democratization. 
Selatan, keduanya sama-sama mensyaratkan adanya pelanggaran hukum agar presiden dapat dikenai impeachment.

Pelibatan lembaga peradilan sebagai penentu seperti halnya di Korea Selatan ataukah tetap diserahkan kepada lembaga politik sebagaimana halnya di Indonesia? Peneliti menggunakan dasar pemikiran dari Carl von Savigny bahwa "hukum merupakan manifestasi dari volkgeist (jiwa bangsa)"69 dan hukum merupakan bagian dari pengalaman dan karakter masyarakat. ${ }^{70}$

Upaya mereformulasi hukum, tentu harus melihat kembali volkgeist dan juga spirit konsitusi dari negara tersebut. Berbicara mengenai volkgeist tidak terlepas dengan karakter suatu bangsa merupakan sistem nilai yang memberikan dorongan bagi peradaban dari sebuah bangsa apakah bangsa itu akan mengalami kemajuan atau kemunduran. Karakter bangsa adalah identitas yang melekat di dalam diri pribadi setiap bangsa, yang terimplementasikan ke dalam praktik kehidupan masyarakat dari suatu bangsa. Setiap bangsa memiliki volkgeist yang akan membedakan antara bangsa yang satu dengan bangsa yang lainnya. ${ }^{71}$ Sedangkan spirit konstitusi berdasarkan pemikiran dari William Hard merupakan hal-hal dasar yang terkandung di dalam konstitusi, ${ }^{72}$ beliau menjelaskan bahwa tubuh konstitusi dapat diubah, terlihat dari dilakukannya amendemen konstitusi Amerika di masa lalu maka tentu akan sering dilakukan amendemen di masa yang akan datang. Beliau melihat pada hasil perubahannya, Kontitusi Amerika tidak melakukan perubahan pada hal-hal dasar karena perubahan yang benar-benar

69 M Z Aulia, "Friedrich Carl von Savigny tentang Hukum: Hukum sebagai Manifestasi Jiwa Bangsa” (2020) 3:1 Undang J Huk 201-236 at 202-203.

70 Luis Kutner, “Legal Philosophers: Savigny: German Lawgiver" (1972) 55:2 Marquette Law Rev 280-295 at 283-284.

71 Listiyono Santoso, Pendidikan Karakter sebagai Strategi Penguatan Wawasan Kebangsaan Mahasiswa (Universitas PGRI Semarang, 2017) at 2.

72 William Hard, "The Spirit of the Constitution" (1936) 185:1 The Annals of the American Academy of Political and Social Science 11-15 at 11. 
mendasar hanya dapat terjadi apabila amendemennya mencapai semangat konstitusi. ${ }^{73}$

Volkgeist dan spirit konstitusi merupakan satu kesatuan yang tidak dapat dipisahkan dalam hal mereformulasi hukum, karena volkgeist menggambarkan kepribadian suatu bangsa atau jiwa bangsa sedangkan spirit konstitusi merupakan landasan atau pemikiran dasar dari terbentuknya hukum di negara tersebut.

Berkaitan dengan proses impeachment di Indonesia, proses ini memiliki waktu maksimal 90 hari, diawali dari DPR memberikan usulan pemberhentian Presiden ke MK, setelah itu MK memeriksa kebenaran dari pendapat DPR tersebut, lalu memberikan dan menyampaikan putusan kepada DPR terkait benar atau tidaknya Presiden telah melakukan pelanggaran hukum atau alasan konstitusional lain sebagaimana yang dituduhkan oleh DPR. Apabila MK melalui putusannya menyatakan benar bahwa Presiden telah melanggar hukum, di sinilah DPR memberikan putusan MK tersebut kepada MPR untuk segera dilaksanakannya sidang istimewa dengan kurun waktu paling lama 30 hari serta memberi kesempatan kepada Presiden untuk melakukan pembelaan terlebih dahulu. Berdasarkan hal tersebut, putusan MK hanya berperan sebagai penengah dalam proses impeachment karena putusan tersebut tidak sebagai eksekutorial atau tidak dapat secara langsung memberhentikan Presiden. ${ }^{74}$

Sedangkan di Korea Selatan, mekanisme impeachment diawali dengan usulan pemberhentian Presiden oleh National Assembly kepada Constitutional Court ${ }^{75}$, kemudian Constitutional Court memberikan

73 Ibid.

74 M Laika Marzuki, "Pemakzulan Presiden/Wakil Presiden Menurut UndangUndang Dasar 1945" (2010) 7:1 J Konstitusi 15-28 at 26.

75 Lihat dalam Naskah Komprehensif Perubahan UUD 1945 Buku VI mengenai Kekuasaan Kehakiman, Edisi Revisi, (Jakarta: Sekretariat Jenderal dan Kepaniteraan Mahkamah Konstitusi, 2010) at 370-371; Pasal 24C ayat (1) UUD NRI 1945; dan Pasal 111 ayat (1) Konstitusi Korea Selatan. Dijelaskan bahwa founding fathers dalam upaya membentuk MK melihat contoh negara Anglo 
putusan untuk langsung memberhentikan Presiden tanpa harus dikembalikan kepada lembaga badan legislatifnya (lembaga legislatif tidak memiliki kekuasaan untuk memutuskan pemberhentian Presiden).

Dari hal tersebut dapat diambil kesimpulan bahwasanya di Indonesia, keputusan tetap berada di tangan lembaga politik, yakni MPR. Sedangkan di Korea Selatan, keputusan final terdapat di lembaga peradilan. Meskipun di Indonesia sendiri belum ada peristiwa Impeachment semenjak Amandemen keempat UUD NRI 1945 dilakukan, namun mekanisme yang ada memiliki kemungkinan terjadi seperti di Amerika Serikat.

Ketika keputusan final Impeachment berada di tangan politik, maka besar kemungkinan anggota parlemen akan membela presiden yang berasal dari satu partai. Praktik di Amerika Serikat membuktikan ketika kasus Impeachment Andrew Johnson yang berasal dari Demokrat, tidak ada satupun orang Demokrat di Senat yang menyetujui Impeachment tersebut, Bill Clinton yang berasal dari Demokrat, tidak ada satupun orang Demokrat di Senat yang menyetujui Impeachment tersebut, dan yang terakhir Donald Trump yang berasal dari Republik, tidak ada satupun anggota senat yang berasal dari partai Republik yang menyetujui usulan Impeachment tersebut.

Artinya jika melihat praktik di Amerika Serikat, ketika seorang partai presiden menguasai senat, maka akan ada kecenderungan untuk menolak Impeachment tersebut, meskipun presiden terbukti bersalah melakukan tindak pidana. Maka dari itu penulis sarankan agar

Saxon yaitu Korea Selatan dimana MK dibentuk sebagai lembaga negara sendiri dan apabila melihat kewenangan yang dimiliki oleh MK Indonesia dengan Korea Selatan memiliki banyak persamaan antara lain: melakukan pengujian terhadap undang-undang, memutus sengketa kewenangan lembaga negara, memutus pembubaran partai politik, dan pemberhentian jabatan, maka MK di Indonesia dan Constitutional Court di Korea Selatan adalah lembaga negara yang sama. 
Indonesia mengikuti Korea Selatan supaya meletakan lembaga peradilan sebagai penentu dari Impeachment.
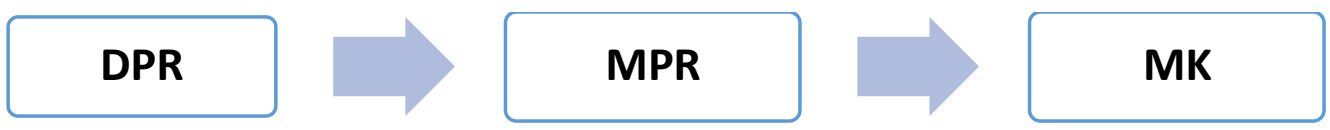

Dengan mekanisme tersebut, harapannya adalah ketika Presiden telah terbukti secara hukum melakukan pidana berat, korupsi, ataupun pengkhianatan, maka tidak perlu ada lagi keputusan politik yang menentukan dalam proses Impeachment tersebut sehingga Presiden benar-benar dapat dikenai hukuman atas pelanggaran konstitusi yang dilakukannya.

\section{KESIMPULAN}

Perbandingan mekanisme Impeachment antara Amerika Serikat, Korea Selatan dan Indonesia, maka terdapat tiga perbedaan yang paling umum, yakni ada yang melibatkan lembaga peradilan dalam prosesnya yakni Indonesia dan Korea Selatan, dan yang hanya melibatkan lembaga perwakilan saja dalam prosesnya, yakni Amerika Serikat. Praktiknya di Amerika Serikat, tiga usaha Impeachment terhadap Presiden gagal akibat tidak memenuhi syarat dua per tiga suara senat, hal tersebut disebabkan belum ada partai yang menguasai secara mayoritas absolut dalam Senat Amerika Serikat dan ketika ada kecenderungan ketika presiden yang di impeach berasal dari partai yang sama dengan anggota senat, maka belum ada kasus anggota senat tersebut menyetujui Impeachment tersebut. sehingga kelemahan yang ada di Amerika Serikat adalah Impeachment yang seharusnya merupakan pelanggaran hukum, justru proses penegakan nya menjadi proses politik.

Praktiknya di Korea Selatan, MK sudah memutuskan dua kasus Impeachment, dimana satu ditolak dikarenakan Mahkamah menganggap kejahatan yang dilakukan tidak menjadi alasan yang cukup untuk menjatuhkan dia dari jabatannya sebagai presiden, dan satu lagi diterima sebab telah melakukan pemerasan terhadap warga negara. Mekanisme di Korea Selatan menjadi masuk akal sebab 
pembuktian pelanggaran hukum yang dilakukan oleh Presiden, tentu haruslah dilakukan dengan mekanisme peradilan dan diselenggarakan oleh lembaga peradilan. Pengalaman kedua negara tersebut dapat dijadikan contoh bagi Indonesia untuk memperbaiki sistem Impeachment di Indonesia, terutama lembaga yang menentukan apakah presiden pantas untuk turun ataukah tidak. Untuk mencegah campur tangan politis yang berlebihan ketika presiden melakukan pelanggaran berat, maka peran MPR sebagai lembaga penentu Impeachment haruslah digantikan dengan MK.

\section{DAFTAR PUSTAKA}

Berger, Raoul, Impeachment, The Constitutional Problems (United States of America: Bantam Books, 1974).

Brown, H Lowell, High Crimes and Misdemeanors in Presidential Impeachment (Palgrave: Macmillan, 2010).

Cruz, Peter de, Comparative Law in a Changing World (London: Cavendish, 1999).

Hoffer, Peter C \& NEH Hull, Impeachment in America, 1635-1805 (New Haven: Yale UP, 1984).

Ibrahim, Johnny, Teori dan Metedologi Penelitian Hukum Normatif (Surabaya: Bayumedia, 2008).

Marzuki, Peter M, Penelitian Hukum (Jakarta: Kencana Prenada Media Group, 2005).

Muhaimin, Metode Penelitian Hukum (Mataram: Mataram University Press, 2020).

Murphy, John, The Impeachment Process (New York: Infobase Publishing, 2007). 
Piispa, Karoliina, Scandals, Shamans, and Samsung: framing analysis of media coverage on the Choi Soon-sil Gate University of Helsinki, 2018) [unpublished].

Posner, Richard, An Affair of State: The Investigation, Impeachment, and Trial of President Clinton (Harvard: Harvard University Press, 1999).

Rehfeld, Andrew, Political Representation, Democratic Legitimacy, and Institutional Design (New York: Cambridge University Press, 2005).

Schlesinger, Rudolf B, Comparative Law: Cases Text Materials, 2d ed (Brooklyn: Foundation Press, 1959).

Soekanto, Soerjono \& Sri Mamuji, Penelitian Hukum Normatif: Suatu Tinjauan Singkat (Jakarta: RajaGrafindo Persada, 1994).

Sunstein, Cass R, Impeaching the President (147 U.PA.L, 1998).

Venter, Francois, Constitutional Comparison: Japan, Germany, Canada $\mathcal{E}$ South Africa as Constitutional State (Cape Town: Juta \& CO Ltd, 2000).

Zoelva, Hamdan, Pemakzulan Presiden di Indonesia (Jakarta: Sinar Grafika, 2011).

Amar, Akhil R, “On Impeaching Presidents” (1999) 28:2 Hofstra Law Review 291-341.

Aulia, M Z, "Friedrich Carl von Savigny tentang Hukum: Hukum sebagai Manifestasi Jiwa Bangsa" (2020) 3:1 Undang: Jurnal Hukum 201-236.

Fatkhurohman \& Miftachus Sjuhad, "Memahami Pemberhentian Presiden (Impeachment) Di Indonesia (Studi Perbandingan Pemberhentian Presiden Soekarno dan Presiden Abdurrahman Wahid)" (2010) 3:1 Jurnal Konstitusi 165-184. 
Fiorina, Morris, Samuel Abrams \& Jeremy Pope, “The 2000 U.S. Presidential Election: Can Retrospective Voting Be Saved?" (2003) 33:2 British Journal of Political Science 163-187.

Gerhardt, Michael J, "Lessons of Impeachment History" (1999) 67:3 George Washington Law Review 603-625.

Hahm, Sung D \& Uk Heo, “The First Female President in South Korea: Park Geun-hye's Leadership and South Korean Democracy" (2017) 53:5 Journal of Asian and African Studies 1-17.

Hard, William, "The Spirit of the Constitution" (1936) 185:1 The Annals of the American Academy of Political and Social Science 115.

Kutner, Luis, “Legal Philosophers: Savigny: German Lawgiver" (1972) 55:2 Marquette Law Review 280-295.

Lee, Youngjae, "Law, Politics, and Impeachment: The Impeachment of Roh Moo-hyun from a Comparative Constitutional Perspective" (2005) 53:2 The American Journal of Comparative Law 403-432.

Marzuki, M Laika, "Pemakzulan Presiden/Wakil Presiden Menurut Undang-Undang Dasar 1945" (2010) 7:1 Jurnal Konstitusi 15-28.

McDowell, Gary L, “High Crimes and Misdeamenors: Recovering the Intensions of the Founder" (1999) 67:1148 Geo Wash Int'1 L Rev.

Prabowo, Edi, “Mekanisme Pemakzulan (Impeachment) Presiden: Studi Perbandingan Negara Indonesia dan Brasil" (2020) 1:2 Journal of Indonesian Law 119-144.

Sefton, James E, “The Impeachment of Andrew Johnson: A Century of Writing" (1968) 14:2 Civil War History 120-147.

Sunstein, Cass R, "Impeaching the President" (1998) 147:2 University of Pennsylvania Law Review 279-315. 
Whittington, Keith E, "Bill Clinton Was No Andrew Johnson: Comparing Two Impeachments" (2000) 2:2 Journal of Constitutional Law 422-465.

"Fission, Fusion, Reform And Failure In South Korean Politics: Roh Moo-Hyun's Administration" in Korea Yearbook (2008) (Leiden: Brill, 2008).

Baker, Peter, “The Senate Acquits President Clinton", (1999), online: washingtonpost.

BBC, "South Korea's presidential scandal", (2018), online: BBC .co $<$ https://www.bbc.co.uk/news/world-asia37971085\&usg=ALkJrhgRROTREHr0vR5m2O41XzaDUz17aA>.

Fandos, Nicholas, "Trump Acquitted of Two Impeachment Charges in Near Party-Line Vote", (2020), online: nytimes.

Glass, Andrew, "House Votes to Impeach Clinton", (2017), online: Politicio <https://www.politico.com/story/2017/10/08/house-votes-toimpeach-clinton-oct-8-1998>.

Herald, Korea, "Park Geun-hye Impeached", (2016), online: koreaherald.

News Hankookicom, "Motion for Impeach Roh Moo Hyun", (2004), online: Hankooki

$<$ https://news.naver.com/main/read.nhn\%3Foid\%3D001\%26aid\%3D 0000591189\&usg=ALkJrhgH3bW6UVO5lelOfVghbfUlArFWag>.

Roh, Jeong-ho, "Crafting and Consolidating Constitutional Democracy in Korea", online: Korea's Democratization.

Roland, Jon, "Meaning of High Crimes and Misdemeanors", (2012), online: Constitution Society $<$ https://constitution.org/cmt/high_crimes.htm>.

Ross, Edmund G, "History of the Impeachment of Andrew Johnson, President of The United States By The House Of Representatives 
and His Trial by The Senate for High Crimes and Misdemeanors in Office 1868", (2000), online: Public Library <http://www.publiclibrary.uk/ebooks/47/98.pdf\&usg=ALkJrhg8v55GpXYZNIdWX6J38n 1_mjYgDg>.

Santoso, Listiyono, Pendidikan Karakter sebagai Strategi Penguatan Wawasan Kebangsaan Mahasiswa (Universitas PGRI Semarang, 2017).

Staff of the Impeachment Inquiry House of Representatives, "Constitutional Grounds for Presidential Impeachment", (1974), online: judiciary.house.gov.

The Independent, "South Korean opposition parties introduce bill to impeach scandal-hit President Park Geun-hye", (2016), online: independent.

US Judiciary Committee, “Constitutional Grounds for Presidential Impeachment: II. The Historical Origins of Impeachment B. The Intentions of the Framers", (2019), online: washingtonpost.

Undang-Undang Nomor 17 Tahun 2014 tentang Majelis Permusyawaratan Rakyat, Dewan Perwakilan Rakyat, Dewan Perwakilan Daerah, dan Dewan Perwakilan Rakyat Daerah. 